\title{
飽和砂の履歴エネルギー吸収状況に及ぼす入力特性の影響 \\ EFFECTS OF INPUT ACCELERATION WAVES ON ABSORBING PROCESS OF HYSTERESIS ENERGY IN SOIL
}

\author{
片田敏行* · 織本慶一** · 小室智昭*** \\ By Toshiyuki KATADA, Keiichi ORIMOTO and Tomoaki KOMURO
}

\begin{abstract}
In this study, the analysis of the absorbing conditions of hysteresis energy of soil was made. The hysteresis energy is calculated using the results of numerical analysis and on-line earthquake response loading test. Especially, the effect of the characteristics of the input acceleration wave is considered.

As the analytical results, the following conclusions were obtained; when an input wave is narrow-banded wave that have one predominant component, the hysteresis energy is largest. And, in wide-banded wave, the hysteresis energy is very small.

Keywords : soil, hysteresis energy, failure, on-line experiment
\end{abstract}

\section{1. まえがき}

近年, 地震動入力エネルギー量と構造物のエネルギー 吸収の能力を対比させて耐震性を確保する極限設計法が 提案されている(1) 3). 地震時において, 構造物に吸収さ れるエネルギー量をもとに耐震設計を行うためには

(1) その構造物がどの程度のエネルギー量でどの程度 破壊するかということを定量的に把握しておくこ と,

(2) エネルギー吸収状況に対する入力特性の影響を把 握しておくこと, が必要である.

(1)について, 鋼部材では鈴木・玉松4),5) が, RC 部材 では家村あるいは西岡ら ${ }^{6)}$ がそのエネルギー吸収能力を 解析している. 土質工学の分野でも破壊現象の 1 つであ る飽和砂地盤の液状化現象に関して, エネルギ一概念を 応用しようという試みが, 片田・阿部らによって行われ

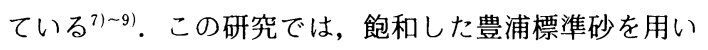
て, 液状化時の過剩間隙水圧の上昇状況とひずみエネル

* 正会員 工博 武蔵工業大学助教授 土木工学科 ( ₹158 世田谷区玉堤 1-28-1)

** 武蔵工業大学土木工学科 (同上)

*** 学生会員 武蔵工業大学大学院修士課程 (同上)
ギー吸収状況を比較し，定性的ではあるが両者の関係が 相関性の高いものであると報告している.さらに，飽和 砂の液状化に要するエネルギ一量も求められている. し かし, 用いた供試体の状態が 2 種類, 入力波が 3 種類と 実験例が少なかったために，より多くの夕イプの入力波 を用いた解析が必要といえる．また，破壊に要する履歴 吸収エネルギ一量は材料である土の種類によっても異な る.この点については片田らにより履歴吸収エネルギー 量の違いが明らかにされている8),9).

しかし, 構造部材の示す復元力特性は材料の違いのみ ならず，地震荷重の不規則性によっても影響を受ける.

したがって, 入力波の不規則性によって, 復元力特性が ビのように変化するかを明らかにする必要が生じる. (2) の項目に関して，たとえば大野・西岡・藤野 ${ }^{10)}$ が入力 である地震動特性とエネルギー量の関係を定量的に把握 することによって, 構造物の破壊の評価を試みている.

土は $10^{-4}$ 程度の小さなひずみでも塑性化するという 点に特徴がある. また, 液状化のように物性が急激に変 化することもある.このように鋼や RCとは異なった 特徴を有する. しかし, 土に関しては解析例は少なく, いまだ履歴エネルギーの吸収状況と破壊程度の関係は明 確ではない.

そこで, 本論文は土の破壊に要する履歴吸収エネル 
ギー量に及ぼす入力特性の影響を数值解析により定量的 に明らかにすることを目的とする，履歴エネルギ一の吸 収量には，入力波特性の振幅の変化のみならず，その継 続時間も大きな要因であると指摘されている11). しかし 本論文では，入力波の振幅の大きさと不規則性が履歴工 ネルギーの吸収状況に与える影響を解析する.

\section{2. 履歴エネルギー算出方法と解析条件}

\section{（1）エネルギー量の算出方法}

本研究では, 最も基本的な力学モデルである 1 自由度 系のばね-質点系モデルを用いて，入力波の影響を明ら かにする.この力学モデルを用いて，種々の非線形復元 力特性を有する振動方程式を線形加速度法により応答解 析を行う．その解析結果よりエネルギー量を算出する. モデル化の詳細については文献 9）を参照されたい。

1 自由度系の非線形復元力によるエネルギー平衡式は 次式で与えられる.

$$
\begin{aligned}
& \int_{0}^{t} m \ddot{x}(t) \dot{x}(t) d t+\int_{0}^{t} c \dot{x}(t) \dot{x}(t) d t \\
& +\int_{0}^{t} R(t, x) \dot{x}(t) d t=-\int_{0}^{t} m \ddot{y}(t) \dot{x}(t) d t
\end{aligned}
$$

式 （1）の左辺第 3 項が非線形復元力による履歴エネ ルギー量である.

（2）用いた実地震加速度記録とその特徵

履歴エネルギーの吸収状況と入力波の関係を調べるた め, 17 種類の実地震記録を選び出した．表一1に各波形 の地震名，観測地点等を示す．観測記録の時間間隔は 0.02 秒であり，主要動が完全に含まれるように継続時 間を 60 秒と統一した． 60 秒よりも長く観測された波形 に関してはそれ以降の記録は削除した。また，1つの入 力波に対して，最大入力加速度を $100 \mathrm{gal}, 200 \mathrm{gal}$, $300 \mathrm{gal}$ に正規化した 3 種類の波を解析に用いた。

17 種類の実地震記録は，時刻歴あるいはフーリエス ペクトルで比較すると波形に特徴がみられる.たとえば, 秋田港記録 $(\mathrm{NS})$, 品川記録 (EW), 清水一三保記録 (NS) にはパルス状の大加速度がみられる. 大船渡記録（NS， EW）には顕著な卓越振動数がみられ，きわめて狭帯域 成分の波である。一方，八戸記録 $(\mathrm{NS}, \mathrm{EW})$ には顥 著な卓越振動数はなく，広帯域の周波数成分を有する.

\section{（3）解析条件および用いたパラメーター}

解析に用いた非線形復元力モデルは, 式 (2) に示す 修正 R. O.G. モデルである12),13)．このモデルを用いて 応答解析を行い, 入力波の特性によって履歴吸収エネル ギー量がどのように変化するかを検討する.

骨格曲線 $: \gamma=\frac{\tau}{G_{\max }}\left(1+\alpha|\tau|^{\beta}\right), \quad(\alpha, \beta$ は定数 $)$

\begin{tabular}{|c|c|c|c|c|}
\hline 名称 & 地震名 & 霓測地点 & 方向成分 & 地震発生日時 \\
\hline JS 1 & 日本海中部地霆 & 秋田港湾 & $\mathrm{E}-\mathrm{W}$ & 1983.5 .26 \\
\hline JS2 & 日本海中部地震 & 秋田港湾 & $N-S$ & 1983.5 .2 \\
\hline JS 3 & 十幐沖地震 & 青森港 & $N-S$ & 1968.5 .16 \\
\hline JS5 & 土联沖地霍 & 大船渡港 & $N-S$ & 1968.5 .18 \\
\hline JSE & 十勝沖地震 & 大船渡港 & $\mathrm{E}-\mathrm{W}^{\prime}$ & 1968.5 . \\
\hline JS7 & 十勝沖地霆余震 & 八戸 & $E-W$ & 1968.6 \\
\hline JSE & 十勝沖地签余藏 & 八戸 & $\mathrm{N}-\mathrm{S}$ & 1968.6. \\
\hline JS 9 & 埼玉琹中部地震 & 品川 & $N-S$ & 1968.7. \\
\hline JS 10 & 埼玉県中部地䗅 & 品川 & $\mathrm{E}-\mathrm{W}$ & 1968.7. \\
\hline JS11 & 十勝沖地零 & 室荿 & $N-S$ & 1968.5 .16 \\
\hline JS 15 & 日向淁地震 & 紐臬 & $N-S$ & 1969.4 .21 \\
\hline$J S 1 \epsilon_{i}$ & 日问滋地地 & 細岛 & $E-W$ & 1969.4 .21 \\
\hline JS17 & & 四日市千才 & $N-S$ & 1971.1 \\
\hline JS18 & & 酉日市千才 & $E-W$ & 1971.1 .5 \\
\hline JS20 & & 錭路 & $E-W$ & 1973.6 .17 \\
\hline JS21 & 伊豆大量近海地至 & 清水一三保 & $E-W$ & 1978.1 .14 \\
\hline JS22 & 伊豆大島近海地焉 & 清水一三保 & $\mathrm{N}-\mathrm{S}$ & 1978.1 .14 \\
\hline
\end{tabular}

表一1 解析に用いた実地露記録（港湾技研記録）14) -21)

\begin{tabular}{|c|c|c|c|}
\hline \multicolumn{2}{|l|}{ ハラメーター } & \multicolumn{2}{|c|}{ 数值 } \\
\hline 単位体積重量 & $\rho$ & 1. 8 & $\mathrm{gf} / \mathrm{Cm}^{3}$ \\
\hline 間隙比 & $e$ & 0.7 & \\
\hline 内部摩瑏角 & $\phi$ & $30^{\circ}$ & \\
\hline 静止土圧係数 & Ko & 0.6 & \\
\hline 粘性减衰定数 & $\beta$ & 0.1 & \\
\hline 固 有 振 動数 & fo & 2.2 & $\mathrm{H} \mathrm{z}$ \\
\hline
\end{tabular}

表一2 砂の物理定数

履歴曲線 $: \gamma=\gamma^{*}+\frac{1}{G_{\max }}\left(\tau-\tau^{*}\right)\left[1+\alpha\left(\frac{\left|\tau-\tau^{*}\right|}{2}\right)^{\beta}\right]$ ただし， $\tau^{*}$ と $\gamma^{*}$ はそれぞれ応力とひずみで履歴曲線 を描いた場合の任意の反転する点である。

解析対象とした地盤は豊浦標準砂のような粒径の整つ た，丸い乾燥した砂の地盤とした。砂の物理状態は表一 2 のように仮定し，解析を行った。これらの物理定数よ り, 復元力関数モデルに必要なパラメーターを参考文献 13）にある提案式を用いて算出した。すすなわち，初期最 大せん断剛性 $G_{\text {max }}$ は,

$$
\begin{aligned}
G_{\max } & =900 \frac{(2.17-e)^{2}}{1+e}\left(\frac{1+2 K_{0}}{3} \rho\right)^{0.4} \frac{1}{1.4} H^{0.4} \\
\therefore G_{\max } & =913 \mathrm{kgf} / \mathrm{cm}^{2}
\end{aligned}
$$

初期最大せん断応力 $\tau_{\text {max }}$ は,

$$
\begin{aligned}
\tau_{\max } & =\left\{\left(\frac{1+K_{0}}{2} \sin \phi\right)^{2}-\left(\frac{1-K_{0}}{2}\right)^{2}\right\}^{0.5} \rho \frac{1}{1.4} H^{0.4} \\
\therefore & \tau_{\max }=0.269 \mathrm{kgf} / \mathrm{cm}^{2}
\end{aligned}
$$

初期最大履歴減衰係数 $h_{\max }$ は,

$$
\begin{aligned}
h_{\max } & =(33-1.5 \log N) / 100 \\
\therefore & h_{\max }=0.320
\end{aligned}
$$

となる，ただし， $H$ は想定地盤の層厚， $N$ は $N$ 值であ る. 


\section{3. 入力波の違いによる履歴エネルギーの吸収 状況の変化}

\section{（1）入力波と履歴エネルギー吸収量の関係}

最終的な履歴吸収エネルギー量と入力波の関係を図一 1 に示す. 図一1をみてもわかるように，入力波が異な れば履歴吸収エネルギー量が異なるという結果が得られ ている.すなわち，大船渡記録 (NS) のとき最大になり， 室蘭記録（NS）のとき最小になった. 最大入力加速度 $300 \mathrm{gal}$ のときで, 約 53 倍の違いが生じている.

なお, 17 波のうち, 品川記録 $(\mathrm{EW})$, 室蘭記録 $(\mathrm{NS})$ および細島記録（NS，EW）の 4 つの入力波を用いた オンライン実験では液状化しなかった。

（2）最大吸収量の入力波と最小吸収量の入力波の比 較

図一2 は履歴エネルギーの吸収量が最大となる場合 の, 図一3 は最小となる場合の応答解析結果を示してい る.フーリエ・スペクトル（図一4，5）を用いて，入力 波を比較してわかることは, 周波数成分が広帯域の波で は吸収量が小さく, 単一成分が卓越した狭帯域の周波数

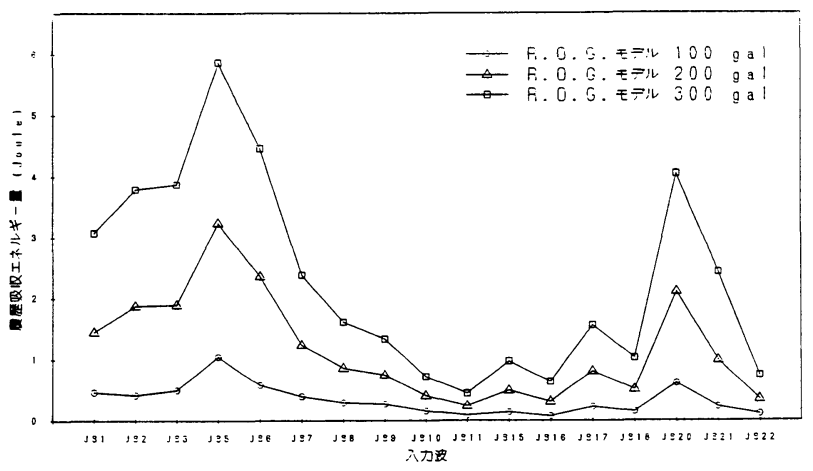

図一1 入力波と履歴吸収エネルギー量の関係 (数值解析による結果)

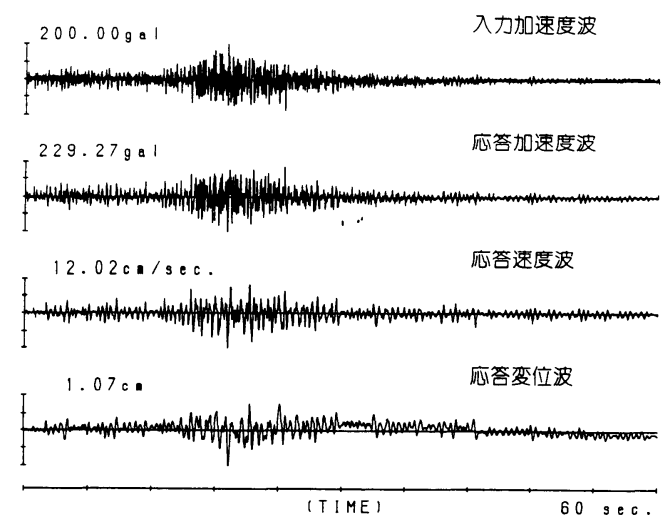

図一3 履歴吸収エネルギー量が最小の場合 (十勝沖地震室蘭記録 NS 成分波)
成分の入力波では，吸収量が大きくなっている，後者の ような特徴を有する入力波はメキシコ地震においてメキ シコ・シティで観測され，建物に大きな被害を与えてい $ろ^{221}$.

\section{4. 履歴エネルギーの吸収量と波形特性の関係}

\section{（1） 波形特性を表わす特性值 ${ }^{23}$}

地震動波形を表わす代表的な特性値として，(1)全パ ワー, (2)絶対平均加速度, (3)平均パワー, (4)最大加速度, (5)継続時間なざがある．全パワ一，絶対平均加速度の定 義を式（6)，（7）に示す。これらのうち本論文で用い た入力波の最大加速度と継続時間は一定とした。そこで, 波形特性值として代表的な全パワー，および絶対平均加

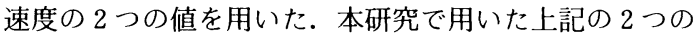
值はいずれも振幅レベルの特性值である.

(1) 絶対平均加速度は次式で定義された式である.

$$
|\ddot{y}|_{\mathrm{ave}}=\frac{1}{T_{d}} \int_{0}^{T_{d}}|\ddot{y}(t)| d t
$$

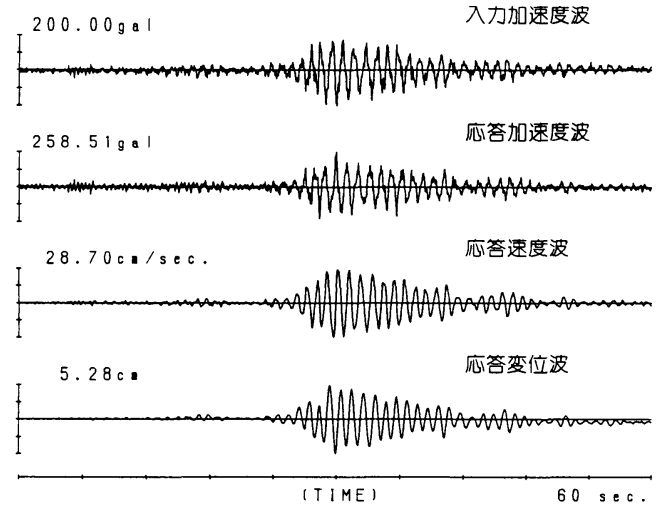

図一2＼cjkstart履歴吸収エネルギー䡒が最大の場合

(十勝沖地震大船渡港湾記録 NS 成分波)

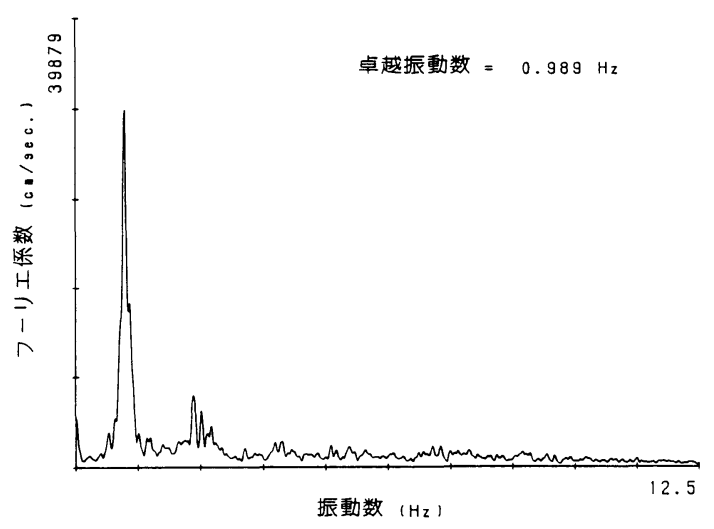

図一4 履歴吸収エネルギー量が最大の場合のフーリエスペクト ル (十勝沖地震大船渡港湾記録 NS 成分波) 


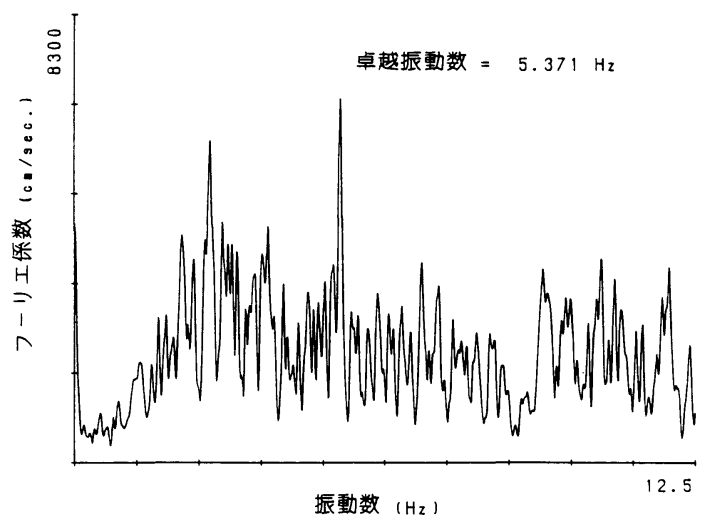

図一5 履歷吸収エネルギー具が最小の場合のフーリエスペクト ル (十勝沖地震室蘭記録 NS 成分波)

この特性值は振幅レベルの平均であり, 地震動のもつ 単位時間当たりの加速度である.

(2) 加速度の全パワーは次式で定義された式である. $P=\int_{0}^{T_{d}}(\ddot{y}(t))^{2} d t$

この特性值は地震動のパワーと関係付けられる.また, 構造物の破壊に対するエネルギ一の供給源としての地震 強さの評価方法の 1 つとなり得る.

なお, 式（6),（７）において $\ddot{y}$ は地震加速度記録 の時間 $t$ における加速度値を示す.

\section{（2）履歴エネルギー吸収量と波形特性の相関分析}

まず，履歴エネルギー吸収量と各波形特性との関係を 図一6，7に示す. 図一6，7をみてもわかるように，各 波形特性とも履歴吸収エネルギ一量と高い相関がある. そこで, 各波形特性値ごとに相関分析を行った。その分 析結果を表一3に示す. 各説明変数とも履歴吸収エネル ギ一量の間に約 $0.74 \sim 0.76$ という比較的高い相関がみ られる.また,解析条件として入力波の継続時間を 60 秒, 最大入力加速度を $200 \mathrm{gal}$ と統一しているので, この解 析結果は人力波の周波数特性，あるいは衝撃的，または 持続的といった波の形によるものと思われる.

次に，履歴吸収エネルギ一量を目的変数とし，絶対平 均加速度, 全パワーを説明変数とした重相関分析を行っ

\section{た. 解析の結果は}

重相関係数: 0.76

回㷌推定式: $y=-0.171+0.0047 x_{1}+0.341 x_{2}$

ただし， $y$ :履歴吸収エネルギー (Joule)

$x_{1}$ : 絶対平均加速度

$x_{2}:$ 全パワー

であった。単相関分析の場合と同様に比較的高い重相関 係数が得られた.したがって, 絶対平均加速度と全パワー

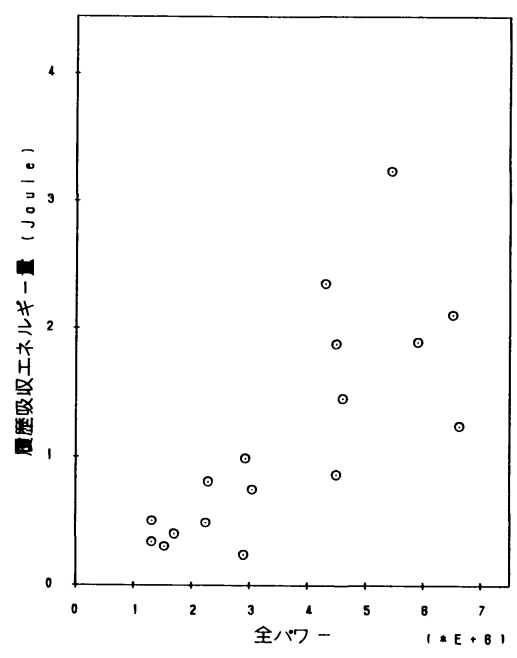

図一6 履歴エネルギー吸収量と全パワーの関係

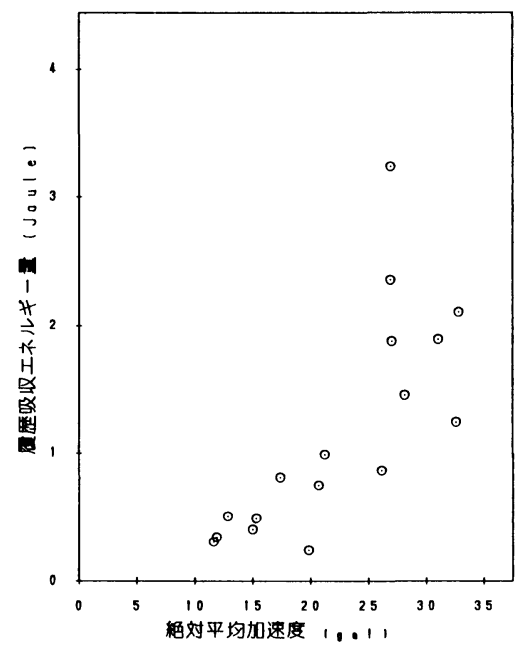

図一7履歴エネルギー吸収量と絶対平均加速度の関係

表一3 履歴吸収エネルギー量と波形特性の単相関分析

\begin{tabular}{c|c|c}
\hline 説明 変数 & 相関係数 & 回㷌 直 線 \\
\hline 絶対平均加速度 & 0.745 & $Y=0.088 X-0.778$ \\
\hline 全パワ- & 0.758 & $Y=0.368 X-0.134$ \\
\hline
\end{tabular}

で履歴吸収エネルギー量を回帰推定できよう.

履歴吸収エネルギー量に関する観測値と回帰推定値を 比較すると, 十勝沖地震大船渡記録 (NS 成分) のよう な狭帯域な周波数特性を有する波で両者が大きく異なっ ている。このことは大船渡記録 (NS 成分) が他の入力 波と周波数特性が異なり, 特別に履歴エネルギ一を良く 吸収するためと思われる（図一8）.

履歴エネルギーを多く吸収する原因として入力波と振 動系が共振することが考えられる.しかし, 本研究で行っ 


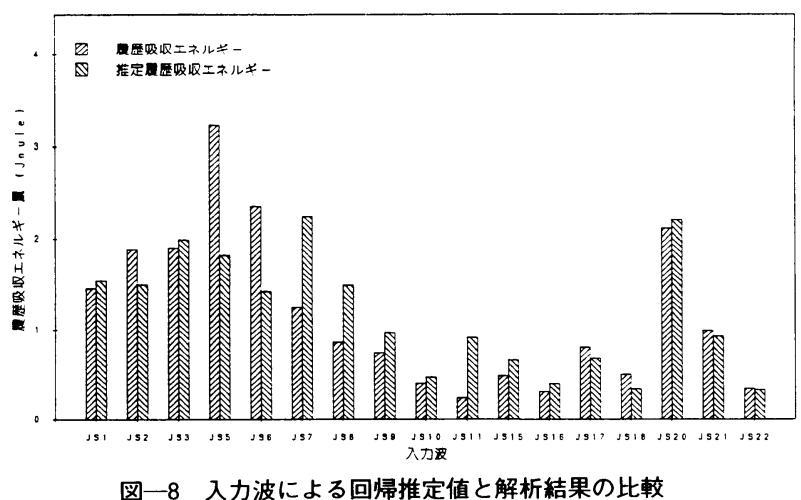

た 17 波の解析結果をみると, 一概に入力波の卓越周期 が地盤モデルの固有周期に近いからといって, 必ずしも 履歴エネルギ一を多く吸収するとはいえないという傾向 がみられる．たとえば，本研究で用いた 17 波の入力波 の中で卓越周期が最も地盤モデルの固有周期に近い入力 波は, JS 10 (表一1 参照) の $1.758 \mathrm{~Hz}$ である.この入 力波を用いた数值解析で得られた履歴吸収エネルギ一量 は 0.155 Joule で, 17 波のうちで 13 番目の值である. また, 仮定した地盤モデルが変われば履歴エネルギ一の 吸収量も変わるので, 式（8）で示した回帰推定式は表 一2のような地盤モデルのときのみに有効である．この 意味では一般性は有していないといえる.

\section{5. 飽和砂の液状化を対象とした破壊状態を含 む場合における入力波の影響}

\section{（1）数值解析より履歴吸収エネルギー量を求める限} 界

数值解析により, 破壊までに要するエネルギー量を精 度良く求めるには, 復元力特性が極端に変化し破壊して いく過程をモデル化しなければならない.しかし, 復元 力特性を関数でモデル化するためには, 応力ーひずみ関 係に種々の仮定と近似を導入する必要がある．このため 大ひずみ領域やさらには破壊領域までの応答を精度良く 求めるのは困難である. それゆえ，その応答值をもとに 履歴吸収エネルギー量を算出した場合, 破壊に要する履 歴吸収エネルギー量あるいは吸収状況が明確ではなくな る.そこで, 材料の破壊状態まで動的試験が可能なオン ライン地震応答載荷実験結果をもとに, 履歴吸収エネル ギー量を算出し，入力波の影響を解析する.

本研究で行うオンライン地震応答載荷実験では, 振動 三軸試験機より復元力を計算機に取り込みながら, 地震 加速度波に対する 1 自由度系の応答変位 $x(t)$ と非線形 復元力 $R(t, x)$ から, 式 (1) の左辺第 3 項を用いて, 履歴エネルギーを算出している. したがって, この履歴 エネルギーは 1 自由度系が非線形応答をし，履歴曲線を
描くことにより消費されるエネルギーに相当する.

履歴エネルギー算出のもとになっている 1 自由度系の 非線形復元力を取り出すのに, 本研究では, 動的振動三 軸試験機を用いている，それゆえ，異なる原理の試験機 (たとえば, 中空站じり試験機)，供試体の作成技術， 供試体の大きさ (寸法効果), 拘束圧, 密度などの違い により，1 自由度系の動特性（固有振動数, 減衰定数） 之入力加速度波（最大值も同じ）が同じであっても，得 られる履歴エネルギー量は異なると思われる.

また，応答速度は，動的三軸試験機に設置された供試 体上端で得られる反力をせん断復元力に変換し，これを 用いた 1 自由度系の応答計算より算出している.

なお，入力加速度波としては数值解析に用いた 17 波 の実地震加速度記録（表一1）を用いた。

\section{（2）オンライン地震応答載荷実験法の原理}

振動系を構成する要素は, 地震時に振動系のもつ固有 振動数や減衰特性の影響を受けて, 地震力が作用する. その結果, 要素の物性が変化し, 振動系全体の動特性も 変化する.この影響を受けて, 要素はさらにその物性を 変化させる.このように, 振動系とそれを構成する要素 は, 互いに影響しあいながら, 変化していく.

オンライン地震応答載荷実験法は, 計算機 (本研究で はマイコンを使用）で振動系全体の地震応答を計算しな がら, 要素 (本研究の場合には砂) の載荷実験を行う方 法である．この方法により，上記に述べたような実際の 現象に近い状態で載荷試験ができる.

なお，土のオンライン地震応答載荷実験では 1 次モ一 ドのみを考慮して, 表層地盤は 1 自由度系でモデル化さ れる.

\section{（3）解析条件および供試体の状態}

入力波の波形特性の違いが履歴エネルギーの吸収状況 に現われるように，解析条件，および供試体の状態はな るべく同一となるように設定した．試料土には豊浦標準 砂を用いた。そして，相対密度が約 $65 \%$ 前後になるよ うに落下高さ $10 \mathrm{~cm}$ から砂を自然落下させて供試体を 


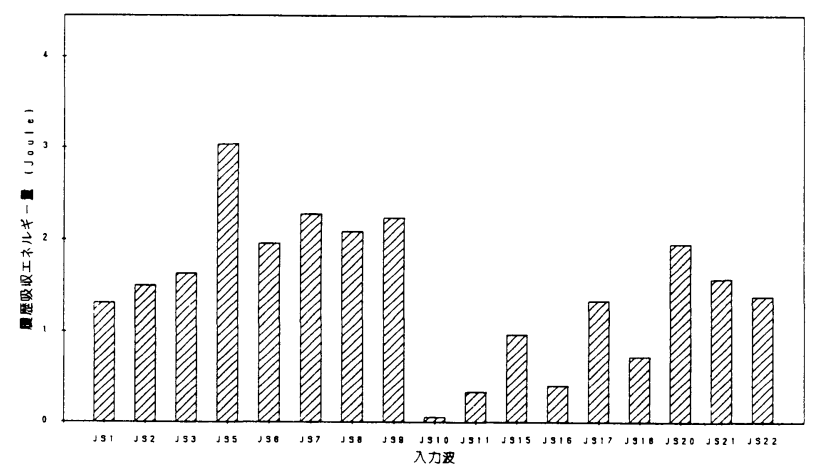

図一9 入力波と液状化に要する履歴吸収エネルギー量の関係

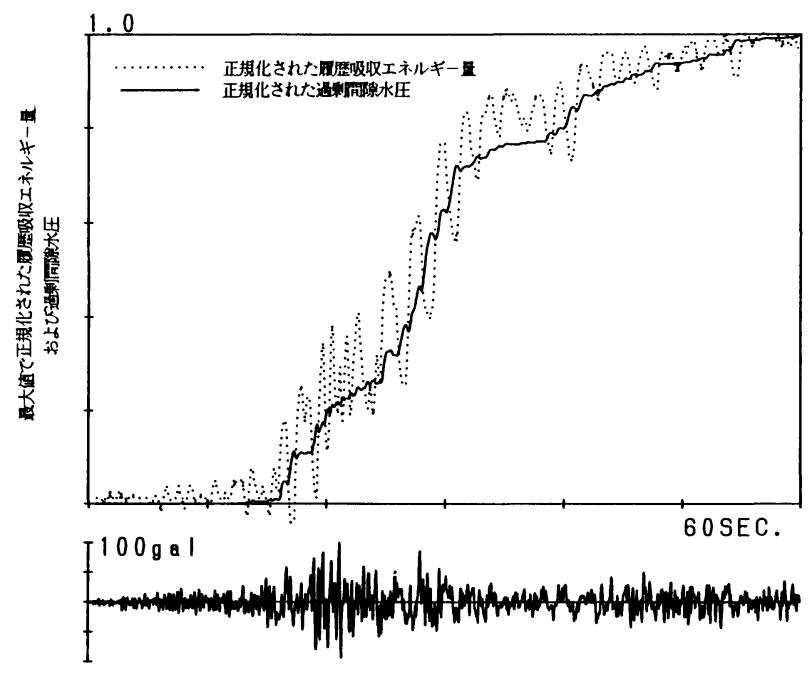

図一10 履歴エネルギーの吸収状況と過剩間隙水圧の上昇過程の比較 (オンライン地震応答載荷実験の実験条件 : 1 自由度系の固有 振動数 $=1.5 \mathrm{~Hz}$, 供試体の相対密度 $D_{r}=32.5 \%$, 拘束圧 1.5 $\mathrm{kgf} / \mathrm{cm}^{2}$, 入力波は日本海中部地震秋田港湾記録 (EW)-JS 1)

作成した．次に，想定された表層地盤の動特性より定ま る 1 自由度系の固有振動数, 粘性減衰定数はそれぞれ $1.5 \mathrm{~Hz}, 10 \%$ と定めた。表一2の值については数值解 析に用いており, $1.5 \mathrm{~Hz}$ の值はオンライン実験に用い た値である.オンライン実験では実物の砂からなる供試 体より復元力を得る．供試体は人が人工的に作成するも のなので，実際よりも軟らかいと思われるので $2.2 \mathrm{~Hz}$ よりも若干小さな值である $1.5 \mathrm{~Hz}$ とした.

固有振動数と粘性减衰定数は特定の地盤を想定したわ けではない。また，三軸試験機にセットする供試体の拘 束压 $p$ は $1.5 \mathrm{kgf} / \mathrm{cm}^{2}$ とした。

これらの解析条件は著者らの既往の論文 ${ }^{8), 91,24)}$ におけ る解析条件と同じとし, 比較検討しやすいように定めた.

（4） 飽和砂に吸収される履歴エネルギー量

完全に液状化した 10 ケースについては間隙水圧が拘
束圧に等しくなるまでの履歴吸収エネルギー量を, 間隙 水圧が拘束圧に等しくなるまで上昇しなかった 3 ケース については, 全継続時間 (60秒) の履歴吸収エネルギー 量を求めた．図一9には，入力波別に吸収された履歴工 ネルギー量を棒グラフで表わしてある.

なお，オンライン地震応答載荷実験結果より算出され た履歴エネルギーの吸収量は, 復元力関数モデルを用い た数值解析より算出された履歴エネルギーの吸収量と比 較しやすいように,供試体の大きさで正規化していない.

（5）入力波の㦀いによる履歴エネルギー吸収状況の 相違

入力波の違いにより液状化した場合としない場合の 2 通りのケースがみられた，完全に液状化したケースと完 全には液状化しなかったケースの, だちらも振動の後半 部分では過剩間隙水圧は，ほとんど上昇していない，完 
全には液状化しなかったケースでは入力加速度波の後半 部の振幅が極端に小さい.このために，過剩間隙水圧が 上昇しなかったと思われる. しかし，入力波の振幅に合 わせるように,過剩間隙水圧は多少ながら昇降している. これに対して, 完全に液状化した場合には, 入力加速度 波の後半部の振幅が大きくとも過剩間隙水圧は一定值を とる。

過㮃間隙水圧の上昇過程は波形の特性により異なって いるが，大別すると次のように分けられる.

(1) 1,2 波の衝撃的な波により急激に過剩間隙水圧 が上昇するもの，

(2) 数回の振動により徐々に過剩間隙水圧が上昇する もの,

(3) (1)亡(2)の中間的な傾向にあるもの.

いずれの場合でも, 過剰間隙水圧の上昇過程と履歴工 ネルギーの吸収状況はよく対応している，図一10をみ てもわかるように, 過剩間隙水圧の上昇過程亡履歴工ネ ルギーの吸収状況はよい対応を示す. 図一10 の履歴吸 収エネルギ一量は, 最大履歴吸収エネルギ一量で正規化 してある. さて, 今回の解析結果の中では(1)の場合, 両 者の対応が良くなっている. また, 対応のあまり良くな いのは, 過剩間隙水圧が昇降を繰り返すときである.そ の理由は, 履歴エネルギーは一度吸収されるとあまり他 のエネルギーに変換されない. そのため, 過剩間隙水圧 が下がっても履歴エネルギーが下がらないため, 両者の 対応が悪くなっている.

完全に液状化した中で最も履歴吸収エネルギー量の多 かったのは, 大船渡記録 (NS) の3.0 Joule であり, 最も少なかったのは, 四日市千才記録 (EW) の 0.7

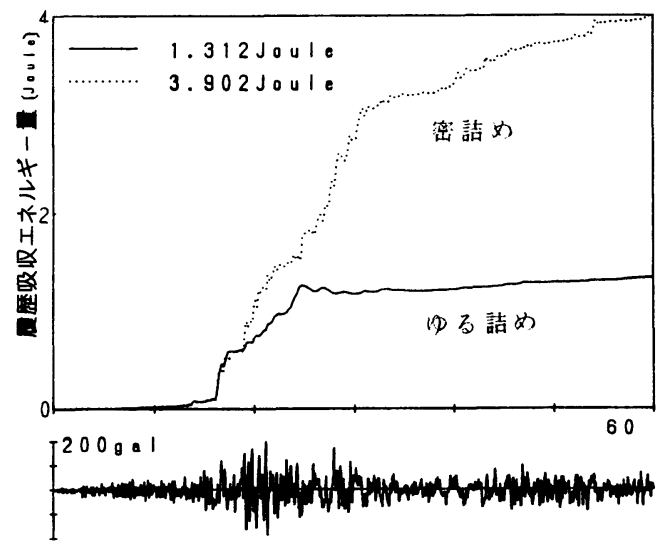

TIME (SEC.)

(実線: ゆる詰め, 破線: 密詰め $\left(D_{r}=80.9 \%\right)$, オンライン地 震応答載荷実験の実験条件 : 1 自由度系の固有振動数 $=1.5 \mathrm{~Hz}$, 拘束圧 $=1.5 \mathrm{kgf} / \mathrm{cm}^{2}$ )

図一11 相対密度による履歴吸収エネルギー量の㦀い
Joule であった，さらに，完全には液状化しなかった品 川記録 $(\mathrm{EW})$, 室蘭記録 $(\mathrm{NS})$, 細島記録 $(\mathrm{NS}, \mathrm{EW})$ がそれぞれ $0.06,0.3 ， 1.0,0.4$ Joule である.このこ とより, 拘束圧が $1.5 \mathrm{kgf} / \mathrm{cm}^{2}$ の下で, 直径 $5 \mathrm{~cm}$, 高 さ $10 \mathrm{~cm}$ の供試体が完全に液状化するには, 少なくと も 1.0 Joule 以上のエネルギー量が必要であるといえ る.

また，液状化したケースでは最大で 3.0 Joule，最小 で 0.7 Joule とおよそ 3 倍程度異なる。この差は同一入 力波を用いて供試体の相対密度だけを変えた場合（図一 11）のゆる詰め砂と密詰め砂における履歴吸収エネル ギー量の違い程度はある. 図一11の数字は, ゆる詰め, および密詰めの場合の最大履歴吸収エネルギー量を示し ている. 衝撃的あるいは持続的な波といった振動形態に より, 液状化の進行状況が異なるために, 供試体の状態 が等しくてもエネルギー量が異なってくるのだと思われ る.

（6）液状化の進行程度と履歴吸収エネルギー貫の関 係

完全に液状化した10 ケースについて過剩間隙水圧比 とそれまでに吸収された履歴吸収エネルギー量の関係を 図一12 に示す. 図一 12 は過剩間隙水圧比が 0.1 だけ上 昇するごとに単位体積履歴吸収エネルギ一量を求め, 両 者の関係をプロットしたものである. 過剩間隙水圧比が 大きくなると履歴吸収エネルギー量がばらついている. 1 つの入力波に関して, 履歴吸収エネルギ一量と過剩間 隙水圧との対応がよいとすれば，ばらつくのは過剰間隙 水圧が高いほど各入力波の波形特性の影響を受けるから だといえる. また，過剩間隙水圧比が飽和砂の損傷程度 を示すと仮定すれば，過剩間隙水圧比が 1.0 になったと きの履歴吸収エネルギー量が液状化に要するエネルギ一 量である.また，過剩間隙水圧比が 0.5 のときの履歴吸 収エネルギー量が, 50 \% 損傷するのに必要なエネルギー 量といえる.

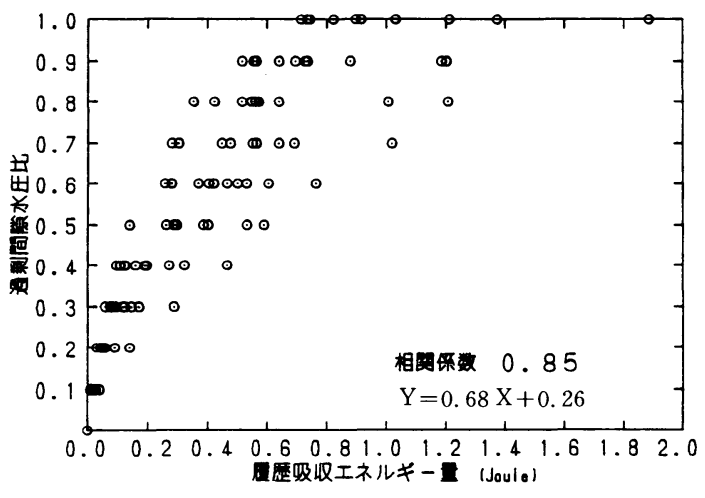

図一12 過剩間隙水圧比と履歴吸収エネルギー量の関係 
図一12より過剩間隙水圧比と履歴吸収エネルギー量 の相関係数を求めたところ, 0.85 となった。履歴吸収 エネルギー量を $X$, 過剩間隙水圧比を $Y$ として, 回㷌 直線を求めると以下の式が得られた。

$Y=0.68 X+0.26$

式（9）より，1.0 Joule のエネルギー吸収量があると $Y=0.94$ 程度の值を示すことが推定される.このこと は, 1.0 Joule によって過剰間隙水圧比が 0.94 となるこ とを意味している.したがって，1.0 Joule でほぼ液状 化状態となる.

\section{6. あとがき}

本研究は地震によって表層地盤に吸収される履歴エネ ルギーの吸収状況に与える入力波の影響を明らかにして いる. 初めに, 破壊まで至らないときの履歴吸収エネル ギーを復元力関数モデルを用いて, 数值解析より求めた. 次に, 破壊する場合として飽和した砂が液状化するまで の履歴吸収エネルギー量をオンライン地震応答載荷実験 により算出した.

本研究で行った解析結果の範囲で, 以下のことがいえ る.

（1）土の種類と地盤状態に応じて, 破壊するまでの 履歴吸収エネルギ一量は求められる.だが，入力である 地震動特性によりその值はばらつく.

（2）すなわち, 入力波の種類が異なると, 最大加速 度值が同じでも, 履歴吸収エネルギ一量は最大で 53 倍 違う。

（3）単一成分波の卓越した狭帯域成分波の入力波の とき履歴吸収エネルギー量が大きくなり, 広帯域成分を 有する入力波のとき履歴吸収エネルギ一量は小さくな る.この傾向は飽和砂のオンライン実験結果より得られ る履歴吸収エネルギー量でも同様であった。

（4）履歴吸収エネルギーは絶対平均加速度, 全パ ワーなどの波形特性との間には比較的高い相関がみられ た.

（5）過剩間隙水圧と履歴吸収エネルギ一量の関係が 式（9）のように得られた.

さらに今後の課題として次のようなことが考えられ る. 破壊するまでに要する履歴吸収エネルギ一量はある 仮定した動的環境のもとに算出されたものなので, 原位 置での実地震による破壊現象とよ゙の程度整合性がとれて いるか求めなければならない。それがわかって初めて求 めた履歴吸収エネルギー量が破壊程度を表わす指標に使 えるであろう。

謝辞：本研究の遂行にあたっては元本学院生の東 山 晃君 (現・福田組)には多大の助力を受けています.
本研究で使用した地震加速度記録は運輸省港湾技術研究 所で公刊されたものです。謝意を表します。

\section{参 考 文 献}

1）秋山 宏：建築物の耐震極限設計, 東京大学出版会, 1980 年 9 月.

2) 加藤 勉 - 秋山 宏: 鋼構造用接骨組の耐震極限設計, 日本建築学会論文報告集, 第 237 号, pp. $59 \sim 65$, 昭和 50 年 11 月.

3）加藤 勉・秋山 宏：強震による構造物へのエネルギー 入力と構造物の損傷, 日本建築学会論文報告集, 第 235 号, pp. $9 \sim 18$, 昭和 50 年 9 月.

4）鈴木敏郎・玉松健一郎：低層鉄骨造骨組柱材のエネル ギー吸収能力に関する研究その 1 , 単調載荷及び定変位 振幅載荷を受ける $\mathrm{H}$ 型鋼柱材のエネルギー吸収能力, 日 本建築学会論文報告集, 第 279 号, pp. $65 \sim 75$, 昭和 54 年 5 月。

5）鈴木敏郎・玉松健一郎：低層鉄骨造骨組柱材のエネル ギ一吸収能力に関する研究その 2 , 変動変位振幅載荷を 受ける $\mathrm{H}$ 型鋼柱材のエネルギ一吸収能力, 日本建築学会 論文集，第 280 号，pp. 19 24，昭和 54 年 6 月.

6）藤掛一典・大野友則・西岡 隆：鉄筋コンクリートラー メンのエネルギー吸収容量に関する実験的研究, 土木学 会論文集, 第 390 号/V-8, 1988.2.

7）片田敏行・阿部幸樹・富山哲次・東山 晃：飽和砂地盤 の液状化過程のエネルギー考察, 第 7 回日本地震工学シ ンポジウム, pp. 655 660, 昭和 61 年 12 月.

8）片田敏行・阿部幸樹・東山 晃：地盤の動的破壊に要す るエネルギー量, 第 19 回地震工学研究発表会講演概要, pp. $225 \sim 228$, 昭和 62 年 7 月.

9）片田敏行・阿部幸樹・東山 晃：ひずみエネルギー蓄積 効果を用いた飽和砂地盤の液状化過程の考察, 土木学会 論文集，第 388 号 $/$ III -3, pp. 43 50, 1987 年 12 月.

10）大野友則・西岡 隆・藤野陽三：構造物が地震時に受け る塑性ひずみエネルギー量の定量的評価, 土木学会論文 集, 第 333 号, pp. 91 99, 1983 年 5 月.

11）伯野元彦・森川 修：地震加速度と構造物破壊の関係に ついての 1 つのシミュレーション, 土木学会論文集, 第 344 号 / I - 1, pp. 299 302, 1984 年 4 月.

12）石原研而：土質動力学の基礎, 鹿島出版会, 1982.

13）足立紀尚・龍岡文夫：土の力学 (III) 一圧密・セン断・動 的解析一，技報堂出版，1981.

14）土田 肇・倉田栄一・須藤克子：1968 年十勝沖地震之そ の余震の港湾地域における強震記録, 港湾技研資料, No. 80, 運輸省港湾技術研究所, 1969.6.

15）土田 肇・倉田栄一・須藤克子：港湾地域強震観測年報 （1968），港湾技研資料，No. 98，運輸省港湾技術研究所, 1970. 3.

16）土田 肇・倉田栄一・須藤克子：港湾地域強震観測年報 (1969)，港湾技研資料，No. 100，運輸省港㴒技術研究所, 1970. 6 .

17）倉田栄一・石坂徳三・土田 肇：港湾地域強震観測年報 （1971），港湾技研資料，No. 136，運輸省港湾技術研究所， 1972. 3.

18）倉田栄一・石坂徳三・土田 肇：港湾地域強震観測年報 
（1973），港湾技研資料，No. 181，運輸省港湾技術研究所, 1974. 3.

19）倉田策一・井合 進・土田 肇: 1978 年伊豆大島近海の 地震における強震記録, 港湾技研資料, No. 317 , 運輸省 港湾技術研究所, 1979.3.

20）倉田栄一・井合 進・横山淑子.土田 肇：1978 年宮城 県沖地震の港湾地域における強震記録, 港湾技研資料, No.319, 運輸省港湾技術研究所, 1979.6.

21）倉田栄一・福原哲夫・野田節男：昭和 58 年 (1983 年) 日本海中部地震の港湾地域における強震記録, 港湾技研
資料, No. 458, 運輸省港湾技術研究所, 1983.9.

22）和泉正哲, ほか：1985 年メキシコ地震に関する調査研究, 文部省科学研究費, 自然災害特別研究突発災害研究成果, 昭和 61 年 3 月.

23）山原 浩：地盤の振動特性を考慮した地震時の地動の推 定 (その 1), 日本建築学会論文報告集, No. 175, 1970.9.

24）東山 晃・片田敏行・成山元一：地震時における土のひ ずみエネルギー蓄積状況の解析, 第 22 回土質工学研究発 表会発表講演集, pp. 531 , 昭和 62 年 6 月.

(1988.9.30 - 受付) 